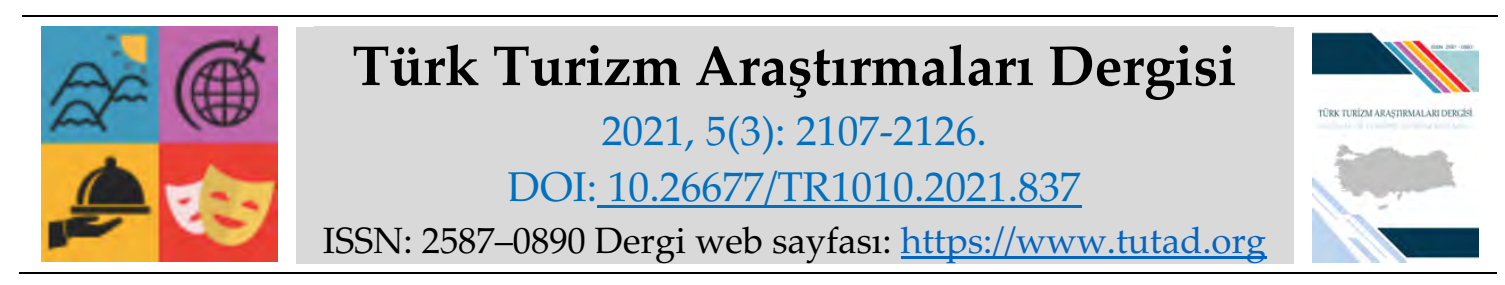

ARASTTIRMA MAKALESİ

\title{
Yayımla veya Yok Ol! Rekreasyon Yönetimi Araştırmaları Nereye Gidiyor? Bibliyometrik Bir Değerlendirme
}

\author{
Dr. Arzu TOKER, Anadolu Üniversitesi, Turizm Fakültesi, Eskişehir, e-posta: \\ arzutoker@anadolu.edu.tr \\ ORCID: https://orcid.org/0000-0002-0619-9941
}

\section{Öz}

Bibliyometrik çalışmalar, seçilen bir konunun bütüncül bir resmini çizmek için son zamanlarda oldukça popüler hâle gelmiştir. Bu çalışma, gelişmekte olan bir bilim alanı olan Rekreasyon Yönetimi Anabilim Dalı'nın lisansüstü tezlerine ışık tutmayı amaçlamaktadır. Bu amaca ulaşmak için Yükseköğretim Kurulu Ulusal Tez Merkezi'nde (YÖK) kayıtlı 134 lisansüstü tez çalışması (2015-2021); yayın yılı, tez türü, araştırma alanı ve konusu, üniversite, araştırma yöntemi, araştırmada kullanılan ölçek türü, araştırmanın geçerlik ve güvenirlik durumu ve analiz tekniği çerçevesinde bibliyometrik değerlendirilmeye tabi tutulmuştur. Analizlere göre, çoğu yüksek lisans tezi olan tezlerin sayısında yıllar itibarıyla görece bir artış vardır. Sonuçlar, Rekreasyon Yönetimi Anabilim Dalı'nda üretilen tezlerin çoğunlukla rekreatif faaliyetler ve rekreasyon katılımı üzerinde yoğunlaştığını göstermiştir. Ayrıca tezlerin araştırma alanlarının ağırlıklı olarak spor ve turizm olduğu tespit edilmiştir. Gazi Üniversitesi-Ankara Hacı Bayram Veli Üniversitesi, en çok üreten üniversitedir. Son olarak, rekreasyon yönetimi alanındaki lisansüstü tezlerin nicel araştırma yöntemleriyle yürütüldüğü ancak veriler değerlendirilirken çoğu tezde herhangi bir geçerlilik uygulamasının yapılmadığı tespit edilmiştir. Ayrıca birçok araştırmacının normallik testlerini yapmamış olmalarına rağmen, parametrik testler uygulamaları da dikkat çekici bir diğer sonuçtur. Nitekim rekreasyon yönetimi çalışmaları henüz belirginleşme aşamasındadır ve başarmak için yapılacak çok iş vardır.

Anahtar Kelimeler: Rekreasyon Yönetimi Araştırmaları, Lisansüstü Rekreasyon Eğitimi, Bibliyometri

Makale Gönderme Tarihi: 16.07.2021

Makale Kabul Tarihi: 02.09.2021

\section{Önerilen Atıf:}

Toker, A. (2021). Yayımla veya Yok Ol! Rekreasyon Yönetimi Araştırmaları Nereye Gidiyor? Bibliyometrik Bir Değerlendirme, Türk Turizm Araştırmaları Dergisi, 5(3): 2107-2126.

(c) 2021 Türk Turizm Araştırmaları Dergisi. 


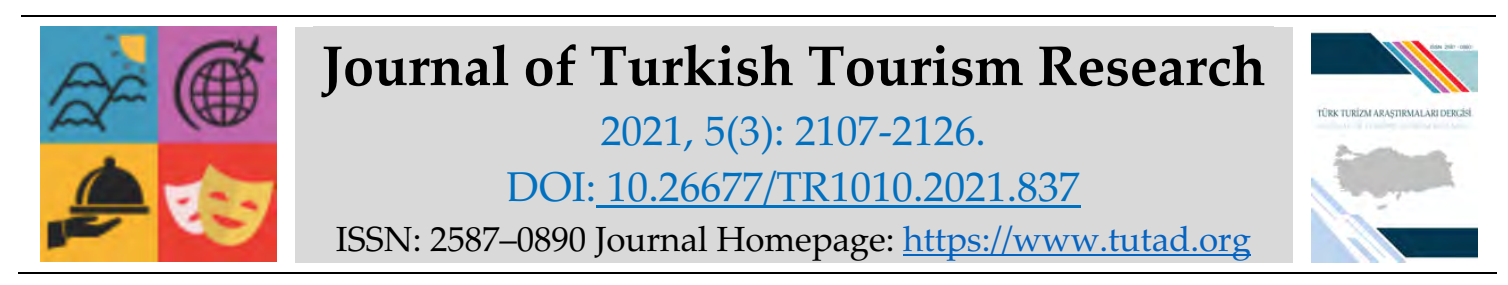

RESEARCH PAPER

\title{
Publish or Perish! Where Are Recreation Management Studies Heading? A Bibliometric Evaluation
}

\author{
Dr. Arzu TOKER, Anadolu University, Faculty of Tourism, Eskişehir, e-mail: \\ arzutoker@anadolu.edu.tr \\ ORCID: https://orcid.org/0000-0002-0619-9941
}

\begin{abstract}
Bibliometric studies have recently been become quite popular to draw a holistic picture of a selected subject. This current study aims to shed light on the department of recreation management postgraduate dissertations which is an emerging scientific field. In order to achieve this aim, 134 postgraduate dissertations registered in the Council of Higher Education National Thesis Center were bibliometrically analyzed under the following parameters: publishing year, type of dissertation, research field and subject, university, research method, scale type used in research, validity and reliability state of the research, and finally analysis technique being used in the study. Based on the analysis performed with SPSS, there is sort of a linear increase in published dissertation years and most of them are maters. Results also demonstrated that recreation management department studies are concentrated mostly on recreative activities and recreation participation. In addition, it was determined that the research fields of dissertations were heavily in sports and tourism. Formerly Gazi University and currently Ankara Hacı Bayram Veli University is where studies are mostly published. Finally, it is worth noting postgraduate dissertations published in recreation management were conducted through quantitative research methods; although, most of them haven't applied any validity assessments during evaluating data. Also, another remarkable finding that researchers were applied parametric tests even though a number of them seem not to even bother performing normality of test. As a matter of fact, that recreation management studies are still on the edge of becoming apparent, there is lots of work to achieve.
\end{abstract}

Keywords: Recreation Management Research, Postgraduate Recreation Education, Bibliometri. Received: 16.07 .2021

Accepted: 02.09.2021

\section{Suggested Citation:}

Toker, A. (2021). Publish or Perish! Where Are Recreation Management Studies Are Heading? A Bibliometric Evaluation, Journal of Turkish Tourism Research, 5(3): 2107-2126.

(C) 2021 Türk Turizm Araştırmaları Dergisi. 


\section{GİRIŞ}

Bibliyometri, bir kütüphane, arşiv veya alanyazında yer alan materyal ve hizmetlerin kullanım kalıplarının incelenmesi ve belirlenmesi amaciyla matematiksel ve istatistiksel yöntemlerin kullanılması; belirli bir bilimsel alanın tarihsel gelişiminin yayınlar, yazarlar ve kullanım açısından analiz edilmesi olarak ifade edilebilir. Bibliyometrinin kavramsal çerçevesinin ilk kez Alan Pritchard'ın 1969 yılında Journal of Documentation'ın Kasım sayısındaki İstatistiksel Bibliyografya mı Bibliyometri mi? (Statistical bibliography or bibliometriecs?) çalışmasında çizildiği öne sürülmektedir (Broadus, 1987:373). Ancak ilk kez Sir Francis Galton'ın (1822-1911) İngiliz Bilim Insanları (English Men of Science) adlı eserinde (1874) sistematik bir yaklaşımla istatistiksel analiz tekniklerinden yararlanarak bilimsel ölçümler yaptığı ve sosyolojik bir çözümleme gerçekleştirerek bibliyometrik bir çalışma yaptığı söylenebilir. 20. yüzyılın ortalarından önce bibliyografik verilerin nicel çalışılması istatistiksel bibliyografya olarak kavramsallaştırılırken (Reitz, 2005) günümüzde çoğunlukla bibliyometri olarak ifade edilmektedir.

Bibliyometri çalışmaları, araştırmanın amacına veya araştırmacının ilgi duyduğu konuya bağlı olarak ortaya koyulmak istenen şey özelinde çeşitli parametrelerle gerçekleştirilebilmektedir. Bu noktada bibliyometri araştırmalarının literatürde oluşan bir konu; hangi alan araştırmacıları tarafından daha çok ele alındığı, araştırmalarda kullanılan yöntemler, tercih edilen araştırma tasarımları, yayın verimliliği, yazar sayıları, en üretken yazar, yayın yapılan dergi adı, türü veya indeksi, yayın dili, başvurulan kaynaklar, atıf sayıları, ilgili konuda en fazla makalenin yazıldığ ülke, yazar iş birlikleri, araştırmada kullanılan analiz teknikleri, konunun ilişkilendirildiği diğer konular gibi örnekleri arttırılabilecek çok sayıda değişken temelinde incelemeye alınabilir. Bibliyometri, disiplinlerin kavramsal, sosyal ve entelektüel açıdan gelişimini (Zupic ve Čater, 2015) kitap, dergi, konferans bildirileri gibi yayımlanan çalışmalardan toplanmış verilerden hareketle temel veya ileri düzey istatistiksel tekniklerin uygulanmasıyla analiz eden bir araçtır (Cobo vd., 2011). Belirli bir alanda veya konuda yer alan çalışmaların, bibliyometrik değerlendirmesinin yapılması, politika geliştiricilerin veya yöneticilerin ilgili konuda atması gereken adımların formüle etmesinin yanı sıra konuyla ilgili genel bir resim çizmekte ve araştırmacıların konuya ilişkin güncel yönelimlerinin ne olduğu hakkında sınıflandırılmış bilgiler içermesi bakımından önem taşımaktadır. Ayrıca bilimsel çalışmalarda sayısal verilerden yararlanılması, bilimsel yöntemin izlenerek karşılaştırmalı, olasılıklara dayalı sonuçlara ulaşılması bakımından belirli bir alanda varılan bilimsel ilerlemenin düzeyinin bir göstergesi olarak kabul edilebilir (Palmer vd., 2005:167).

Turizm fakülteleri bünyesindeki rekreasyon bölümleri 2009 yılından itibaren lisans eğitimi vermeye başlamış; günümüzdeki sayısı ise 119'a ulaşmıştır. Rekreasyon Yönetimi Anabilim Dalı bünyesindeki ilk lisansüstü tez çalışması ise 2015 yılında tamamlanmıştır (YÖK, 2021). Yıllar içindeki bu gelişime bakıldığında her geçen yıl farklı üniversitelerde yeni programların açıldığ ve alanın önemli bir ivme kazandığı görülmektedir. Bu bağlamda mevcut araştırmayla Türkiye'de henüz gelişme aşamasında olan "Rekreasyon Yönetimi Anabilim Dalında" üretilen tez çalışmalarının gelişiminin; lisansüstü tezlerin yayımlandığı üniversite, alan, konu, tür, yöntem, veri toplama araçları, geçerlilik, güvenirlilik ve normallik değerlemesi ve analiz tekniği değişkenleri çerçevesinde ortaya koyulması amaçlanmaktadır. Ele aldığı parametreler açısından bu araştırmanın alandaki gelişim süreçlerine 1şık tutacak, ilgili literatüre katkı sağlayacak ve gelecek araştırmalar için temel bilgiler verecek özgün değere sahip bir kaynak çalışma niteliği taşıdığı düşünülmektedir. Elde edilen sonuçların bu alanda çalışma yürütecek araştırmacılara yalnızca popüler konu, alan, yöntem, ölçme aracı türleri ve kavramlar yönüyle bir bakış açısı değil aynı zamanda çalışmalarda özellikle ölçme ve değerlendirme süreçlerinde dikkat etmeleri ve kaçınmaları gereken noktaların neler olduğunu göstermesi bakımından önem taşıdığı ifade edilebilir. Çalışmanın takip eden bölümlerinde; ilgili literatür özetlenecek, üniversitelerin 
rekreasyon anabilim dallarında yayımlanan tezler ilgili parametreler çerçevesinde değerlendirilecek, bulgular yorumlanacak ve sonuçlara bağlı olarak çeşitli öneriler getirilecektir.

\section{İLGILII LITTERATÜR}

Literatürde çeşitli konularda çeşitli parametrelerin temel alınmasıyla gerçekleştirilen bibliyometrik çalışmalara rastlamak mümkündür. Türkiye'de her yıl belirli bir alan, konu, üniversite, anabilim dalı gibi çeşitli parametreler çerçevesinde yüksek lisans ve doktora tezlerinin kaydedilerek yayımlandığı Yükseköğretim Kurulu Başkanlığı Tez Merkezi araştırmacılara bu anlamda veri sağlamaktadır. Bu anlamda YÖKTEZ, üniversitelerde gerçekleştirilen lisansüstü tez çalışmalarının gelişim süreçlerinin izlenmesiyle belirli bir disiplinle ilgili gelinen aşamanın değerlendirilebilmesine olanak tanımaktadır. Uluslararası ve ulusal literatür incelendiğinde de tezlerin incelenerek belirli bilim alanlarındaki gelişim seyrinin ortaya koyulduğu çok sayıda çalışmaya rastlamak olanaklıdır.

Weiler vd., (2012) Avustralya, Amerika Birleşik Devletleri, Kanada ve Yeni Zelanda'da yayımlanan turizm doktorası tez çalışmalarını etkileyen disiplinlerin çözümlemesini yapmıştır. Bibliyometrik araştırma yaklaşımının temel alındığı araştırmada 1951 ve 2010 yılları arasında ulaşılan 1888 tezin özeti üzerinden gerçekleştirilen çözümleme sonucu psikoloji, çevresel araştırmalar ve antropoloji en fazla çalışılan disiplinler olurken oransal olarak turizm ekonomisi araştırmalarında zaman içerisinde kayda değer bir azalışın meydana geldiği ortaya konulmuştur.

Tourism Management, Journal of Travel Research, Annals of Tourism Research, Journal of Sustainable Tourism dergilerinde 1987 ile 2014 yılları arasında sürdürülebilir turizm araştırmalarıyla ilgili eğilimleri ve araştırmaların gerçekleştirilme biçimlerinin analiz edildiği bibliyometrik bir çalışmada Ruhanen vd. (2015), araştırmacıların en fazla ilgi duydukları araştırma türünün durum çalışması (case study), sürdürülebilir turizm uygulamalarının ilgi duyulan öncü konulardan olduğunu ve son olarak araştırma perspektifi bağlamında planlamanın baskın çoğunlukta olduğunu saptamışlardır.

Vishwakarma ve Mukherjee (2019), bibliyometrik araştırma yaklaşımını kullanarak Turizm Rekreasyon Araştırması Dergisi'nde (Tourism Recreation Research) 1976 ile 2018 yılları arasında yayımlanan çalışmaları yıllık yayın sayısı, atıflar, en fazla atıf alan makale, en üretken yazar ve en fazla makale yayımlayan ülke ve kurumların çeşitliliği gibi anahtar kavramları temel alarak bir araştırma gerçekleştirmiştir. Araştırma sonucunda, Turizm Rekreasyon Araştırması Dergisi'nin yukarıda sıralanan göstergeler temelinde her geçen yıl artan yayın sayısı ile alanda öncü dergilerden biri olduğu ortaya koyulmuştur.

Sosyal medya temasının ele alındığı ağırlama ve turizm araştırmalarının temel alındığ bibliyometrik bir araştırmada Nusair vd. (2019), sosyal medya araştırmalarının; yayımlandığı dergiler, araştırmacı isimleri, ortak yazarlıklar, aldığı atıflar, yapıldığı üniversiteler, ülkeler, ülkeler arası iş birliği karşılaştırması, anahtar kavramları çerçevesinde analizini gerçekleştirmiştir. Araştırma sonucunda sosyal medya araştırmalarının en fazla yayımlandığ derginin Tourism Management, konuyla ilgili en fazla araştırma yapan yazarın Ronald E. Goldsmith; üniversitenin Hong Kong Polytechnic Üniversitesi, en fazla atıf alan derginin Tourism Management; en fazla yayın yapılan ülkelerin Amerika Birleşik Devletleri ve Çin; en çok kullanılan anahtar kavramın ise Tripadvisor olduğunu tespit etmiştir.

Uluslararası bir konferansta (SRFLIS) 2014-2019 yılları arasında sunulan 220 bildirinin; yıllara, ortak yazarlıklarına, yazar cinsiyetlerine, yazar işbirliklerine, yazarların kurumlarına, ülke ve eyaletlerine, çalışma konularına, çalışma kategorilerine, atıf sayılarına, atıflandırılan çalışma türlerine ve çalışmaların sayfa uzunluklarına göre dağılımların parametre olarak belirlendiği 
bibliyometrik bir çalışmada Singh vd. (2020), çalışmaların büyük çoğunluğunun iki yazardan oluştuğunu, toplamda 2720 alıntının yapıldığını ve en fazla atıflandırılan çalışmaların dergi makaleleri olduğunu saptamışlardır. Araştırmacılar ayrıca konferansa en fazla katkı sunan ülkenin Hindistan, maksimum çalışma yayımlayan eyaletin Yeni Delhi olduğunu belirlemiştir.

Disiplinlerarası çalışmaların gerçekleştirildiği turizm alanındaki araştırmalarda öncü disiplinlerin belirlenmesine yönelik yürütülen bibliyometrik bir araştırmada López-Bonilla ve López-Bonilla (2021), İspanyol turizminde ele alınan temel disiplinlere odaklanmıştır. Scopus veri tabanından yararlanılarak 2002-2013 yılları arasında yapılan araştırmaların incelendiği çalışmada, turizm araştırmalarının her geçen yıl doğrusal bir artış gösterdiğii araştırmalarda ele alınan temel disiplinlerin ise sırasıyla; uygulamalı ekonomi, pazarlama, işletme, ekonomi ve işletme için nicel yöntemler, bölgesel coğrafik analiz, sosyoloji ve sosyal psikoloji olduğu saptanmıştır.

Yukarıda örnekleri çoğaltılabilecek çalı̧̧malara paralel olarak son yıllarda lisansüstü tezlere yönelik bibliyometrik çalışmalar da ulusal literatürde oldukça dikkat çekici bir araştırma konusu haline gelmeye başlamıştır. Tezlere ilişkin yapılan bibliyometrik çözümlemelerde çoğunlukla karmaşık istatistiksel tekniklerden çok, temel istatistiksel ve/veya matematiksel yöntemlere başvurulduğu, yapılan çalışmaların çözümlemelerinde; yayın yılı, tezlerin türü ve yayımlandığı üniversite, anabilim dalı, tezin türü, bağlı olunan enstitü, konu dağılımları, danışman unvanları, araştırma deseni, erişilebilir olma durumu, sayfa sayısı aralıkları, kullanılan anahtar kavramlar, tezlerin aldıkları atıf sayısı, veri toplama tekniği ve aracı, dayandığı disiplin, uygulama alanları, yararlanılan kaynak türleri, yazar ve/veya danışman cinsiyetleri gibi çeşitli değişkenlerin temel alınmaktadır (Turan, 2014; Güçlü Nergiz, 2014; Arslan ve Emeksiz, 2016; Aydın ve Arslan, 2016; Lian, vd., 2016; Alimanoğlu ve Ayazlar, 2017; Arslan vd., 2017; Demirbulat ve Dinç, 2017; Sünnetçioğlu vd., 2017; Altaş ve Acar, 2018; Çapar vd., 2018; Gül ve Gül, 2018; Özsoy ve Çokal, 2018; Tayfun vd., 2018; Aydın ve Aksöz, 2019; Büyükşalvarcı ve Keleş, 2019; Çıkrık vd., 2019; Kervankıran vd., 2019; Polat vd., 2019; Aksöz ve Yücel, 2020; Alimanoğlu ve Arıkan Saltık, 2020; Çuhadar ve Morçin, 2020; Köşker, 2020; Ünal ve Bayar, 2020; Yersüren ve Özel, 2020; Zengin ve Atasoy, 2020; Alimanoğlu ve Çolakoğlu, 2021; Boyraz vd. 2021; Yıldırım, 2021).

Ulusal ölçekte ise lisansüstü tezlere ilişkin kapsamlı bir çalışma Turan (2014) tarafından yapılmıştır. Turan (2014), 1984-2013 yılları arasında yayımlanan 1670 "turizm" konulu yüksek lisans tezini; tezin yazarı, tez danışmanın unvanı, tez danışmanının adı, tezin yayımlandığ üniversite, yayımlandığı enstitü, ilgili anabilim dalı, tezin çalışma alanı, uygulama bölgesi, sayfa sayısı parametreleri çerçevesinde incelemiştir. Yapılan incelemeler sonucunda, tezlerin tüm üniversiteler arasında en fazla İstanbul Üniversitesi bünyesinde, en fazla yardımcı doçent unvanlı öğretim üyelerinin danışmanlığında, en fazla pazarlama alanında yoğunlaştığı ortaya çıkmıştır. Ayrıca, tezlerin uygulama alanlarının ağırlıklı olarak Antalya olduğu ve 2000'li yıllar itibarıyla yüksek lisans tezlerinin sayısında önemli artışlar yaşandığı ortaya çıkmıştır. Güçlü Nergiz (2014) ise araştırmasında lisansüstü tez çalışmalarının kapsamını genişleterek 1565 yüksek lisans ve 783 doktora tezi olmak üzere toplam 2348 tez incelemiştir. Yükseköğretim Kurulu resmî internet sayfasındaki 1990-2013 yılları arasında yayımlanan tezler turizm, otel, otel işletmesi, seyahat acentası ve yiyecek-içecek işletmesi anahtar kelimeleri ile taranmış; tür, dil, yıl, üniversite, enstitü, anabilim dalı ve konu gibi bibliyometrik özellikleri açısından incelenmiştir. Araştırma sonucunda en fazla yüksek lisans tezinin Gazi Üniversitesi'nde, doktora tezinin ise Dokuz Eylül Üniversitesi'nde hazırlandığı belirlenmiş̧tir. Zaman açısından incelendiğinde en fazla sayıda tezin 2010-2013 yılları arasında hazırlandığı görülmüştür. Konu açısından yüksek lisans tezlerinde çoğunlukla turizm, işletme ve mimarlık konulu tezler; doktora tezlerinde ise turizm, işletme ve coğrafya konulu tezler ön plana çıkmıştır. 
Büyükşalvarcı ve Keleş (2019) turizm alanında yazılan lisansüstü tezlerin bibliyometrik çözümlemesini tür ve yıl değişkenleri temelinde gerçekleştirdikleri araştırma sonucunda, turizm ve çevre konulu çalışmaların en fazla 1996 yüksek lisans çalışmasının gerçekleştirildiği, turizm pazarlaması yazılan tezlerin en popüler olduğu tarihin 1998 yılı olduğu ve bu yılda en fazla yüksek lisans tezi yazıldığı belirlenmiştir. Turizm ana başlığı içerisinde rekreasyon anahtar kavramının en sık kullanıldı ̆̆ı tarihin 2002 olduğu belirlenmiştir. Araştırmacılar ayrıca 2016-2018 yıllarının turizm bağlamında sürdürülebilirlik konusunda, 2018 yılında ise yönetim konusunda yazılan yüksek lisans tezlerinin revaçta olduğunu belirlemiştir.

Sonraki yıllarda yapılan çalışmalara bakıldığında, konu ve alan özelinde yapılan çalışmaların sıklaştığı görülmektedir. Örneğin Demirbulat ve Dinç (2017), 1987-2015 yılları arasında turizm literatüründe sürdürülebilir turizm ile ilgili lisansüstü tezleri çeşitli parametreler çerçevesinde bibliyometrik özelliklerini belirlemiştir. Buna göre, Yükseköğretim Kurulu veri tabanında yer alan ve 1987-2015 yılları arasında sürdürülebilir turizm konusunda yayımlanmış olan 41 yüksek lisans ve 21 doktora; tez türü, yayımlandığı yıl, yayımlandığı üniversite, yayımlandığı enstitü, yayımlandığı anabilim dalı ve tezin çalışma konusu gibi bibliyometrik özellikleri açısından incelenmiştir. Veri tabanında yer alan çalışmalara ilişkin bilgiler istatistiki analiz paket programına yüklenerek, verilerin sıklık ve yüzde analizleri yapılmıştır. Yapılan incelemeler sonucunda, üniversiteler arasında en fazla lisansüstü tezin İstanbul Üniversitesi bünyesinde hazırlandığı belirlenmiştir.

Gastronomi alanında 1987-2018 yılları arasında ulusal ölçekte gerçekleştirilen 42 lisansüstü tezin bibliyometrik profilini tez türü, dili, yayımlandığı yıl-üniversite-enstitü-anabilim dalı, sayfa sayısı, danışman unvanı, veri toplama aracı, program adı ve enstitü parametreleri çerçevesinde inceleyen Altaş ve Acar (2018) araştırma sonucunda alanda en fazla lisansüstü tezin; Gazi Üniversitesi'nde ( $\mathrm{n}=8), 2016$ yılında ( $\mathrm{n}=15)$, yüksek lisans tezi (42), Türkçe dilinde $(\mathrm{n}=40)$, sosyal bilimler enstitüsünde $(n=44)$, turizm işletmeciliği alanında $(n=13)$, sayfa sayısının 101-200 $(n=35)$, veri toplama aracının $(n=26)$, danışman unvanının doktor öğretim üyesi $(n=27)$ olduğunu belirleyerek elde edilen sonuçların gelecekte araştırmacılara kolaylık sağlayacağını vurgulamıştır.

Turist rehberliği alanında 1989 ile 2018 yılları arasında yayımlanan lisansüstü tezlerin bibliyometrik analizinin gerçekleştirildiği bir çalışmada; tezlerin türü, yayımlandığ üniversite, enstitü, anabilim dalı, aldıkları atıf sayıları, danışman unvanları, yöntem, veri toplama tekniği, dayandığı disiplin ve uygulama alanlarına göre dağılımları incelenmiştir. Veri analizleri; en fazla çalışmanın 2015 ile 2018 yılları arasında yapıldığı; enstitüye göre sosyal bilimler, tez türüne göre yüksek lisans, tezi yöneten danışman unvanlarına göre ise doçent doktorun çoğunlukta olduğu belirlenmiştir. Anabilim dallarına göre dağılımları incelenen tezlerin ağırlıklı olarak turizm işletmeciliği, konularına göre dağılımlarının turizm rehberliği, hizmet kalitesi ve turist memnuniyeti ve kurumlara göre mezuniyet dağılımları incelenen tezlerin en fazla Balıkesir Üniversitesi'nden yapıldığı saptanmıştır (Zengin ve Atasoy, 2020). Turist rehberliği alanında 1989 ile 2019 yılları arasında yayımlanan lisansüstü tezlerin bibliyometrik analiziyle ilgili benzer bir araştırma gerçekleştiren Örnek ve Karamustafa (2020) yukarıdaki araştırmadan farklı olarak tez danışmanlarının en fazla doktor öğretim üyesi olduğunu belirlemiştir. Araştırma desenlerine göre incelenen çalışmaların en fazla nicel, örneklem büyüklüklerinin 501 ve üzeri, araştırma katılımcılarının rehberler, çalışmalarda kullanılan veri toplama tekniğinin anket, kaynak dağılımlarının yüksek lisans için yabancı, doktora için ise yerli baskın, sayfa sayısı ağırlıklarının ise 151-200, en sık kullanılan anahtar kavramın turist olduğunu saptamıştır. Yukarıda açıklananlara ek olarak turist rehberliği alanının bibliyometrik incelemesinin gerçekleştirildiği farklı araştırmalarda benzer parametrelerin temel alınarak benzer sonuçların elde edildiği görülmüştür (Arıkan Saltık, 2020; Özsoy ve Çokal, 2018). 
Boş zaman ve rekreasyon alanında 1987-2019 yılları arasında yayımlanan 536 lisansüstü tez çalışmasının; yayımlandıkları yıl, anabilim dalları, tez türü ve yöntem, anahtar kavramlar, veri değerlendirme teknikleri, alana ait alt boyutlar ve alanla ilişkilendirilen kavramlar parametrelerini temel alarak bibliyometrik analizini gerçekleştiren Yersüren ve Özel (2020), araştırma sonucunda ilgili konuda en fazla tezin 2019 yılında yapıldığını, en fazla mezunun yüksek lisans türünde ve beden eğitimi ve spor bilimleri anabilim dalında verildiğini belirlemiştir. Araştırmacılar lisansüstü tezlerde en sık kullanılan anahtar kavramın rekreasyon, veri değerlendirme tekniğinin temel betimsel istatistikler, alt boyutun ise rekreasyon faaliyetleri ve etkinlikler olduğunu saptamıştır. Son olarak çalışmada, lisansüstü tezlerde rekreasyon ve boş zaman alanıyla ilişkilendirilen kavramların en fazla turizm, spor ve peyzaj olduğunu ortaya koymuştur (Yersüren ve Özel, 2020).

\section{YÖNTEM}

Türkiye'de rekreasyon alanındaki eğitimin, Yedinci Beş Yıllık Kalkınma Planı'nda (1996-2000); "boş zamanların değerlendirilmesinde eğitim ve organizasyon faaliyetlerini yürütecek insan gücünün yetiştirilmesi amacıyla üniversitelerde rekreasyon ana bilim dalı tesis edileceği" (Yedinci Beş Yıllık Kalkınma Planı, 2021) yönündeki değerlendirmeyi takiben, Yükseköğretim Kurulu'nun 12.04.2000 tarihli toplantısında beden eğitimi ve spor yüksekokulları bünyesinde verilmeye başlaması kararlaştıılmıştır (Baştuğ vd., 2017:3897). Lisans seviyesinde ilk kez 2000-2001 EğitimÖğretim yılında Muğla Üniversitesi Beden Eğitimi ve Spor Yüksek Okulu'nda rekreasyon eğitimi verilmeye başlanmıştır. Rekreasyon eğitiminin turizm alanında "Rekreasyon Yönetimi" bölümleri açılarak verilmeye başlanması ise 13 Kasım 2009 tarihli ve 27405 Sayılı Resmî Gazete'de yayımlandığı üzere turizm fakültelerinin kurulma kararı ile gerçekleşmiştir (Zorba, 2007).

Günümüzde 207 üniversitenin (vakıf ve devlet) 76'sı Spor Bilimleri Fakülteleri ve Beden Eğitimi ve Spor Yüksekokullarında, 43'ü ise Rekreasyon Yönetimi altında turizm fakülteleri, turizm ve otel işletmeciliği yüksek okulları, uygulamalı bilimler fakülte ve yüksek okullarında olmak üzere 119 üniversitede rekreasyon eğitimi verilmektedir (https://istatistik.yok.gov.tr/). Akdeniz Üniversitesi, Batman Üniversitesi, Ankara Hacı Bayram Veli Üniversitesi, Trakya Üniversitesi, Manisa Celal Bayar Üniversitesi ve Necmettin Erbakan Üniversitesi'nde lisansüstü eğitim verilmektedir. Tüm bu bilgilerden hareketle Türkiye'de rekreasyon eğitimine hem lisans hem de lisansüstü düzeyde önem verildiği rahatlıkla söylenebilir.

Türkiye'de rekreasyonu doğrudan konu alan ve Turizm Anabilim Dalı'nda yazılan ilk doktora tezi 1982 yllına; ilk yüksek lisans tezi ise 1990 yılına tarihlenmektedir (Yükseköğretim Kurulu Başkanlığı, 2021). Rekreasyon konusundaki ilk makale ise Türkiye'nin turizm alanındaki ilk süreli yayını olan Turizm İşletmeciliği Dergisi'nde 1980 yılında yayımlanan makale olmuştur (İçöz ve Kozak, 1999). 40 yılı aşkın süredir turizm alanyazınında yer bulan rekreasyon konusunun hem bilimsel hem de sektörel uzmanlaşma gerektirmesi ve kalitesini artırması beklentisi ile 2013 yılından beri Rekreasyon Yönetimi Anabilim dallarında lisansüstü eğitim verilmektedir. Gelişmekte olan rekreasyon yönetimi anabilim dallarında hazırlanan ve lisansüstü eğitim sürecinin en önemli çıktısı olarak kabul edilen tezlerin mevcut durumuna ışık tutabilmek için araştırma kapsamı yalnızca ilgili anabilim dalıyla sınırlı tutulmuştur. Mevcut çalışma ile Türkiye'de üniversitelerin Rekreasyon Yönetimi Anabilim Dalı'nda yayımlanan tezlerin aşağıda sıralanan özellikler açısından incelenmesi amaçlanmıştır:

I. Yayımlanan tezler hangi alan ve konularda yapılmaktadır?

II. İlk çalışmanın yapıldığı zamandan günümüze kadar yıl temelinde tez türlerine göre dağılımlar nasıldır? 
III. Çalışmalarda hangi yöntemler kullanılmıştır?

IV. Çalışmaların geçerlilik, güvenirlilik veya güvenduyulabilirlik değerlemeleri yapılmış midir?

V. Çalışmalarda hangi tür ölçme araçları kullanılmıştır?

VI. Normallik varsayımını ne ölçüde sağladığına ilişkin analizler yapılıış mıdır?

VII. Çalışmalarda hangi istatistiksel tekniklerden (nicel araştırmalar için) yararlanılmıştır?

Yukarıda sıralanan özelliklere açıklık getirmek amacıyla mevcut araştırma kapsamında izlenen çalışma akış şeması şu şekildedir:

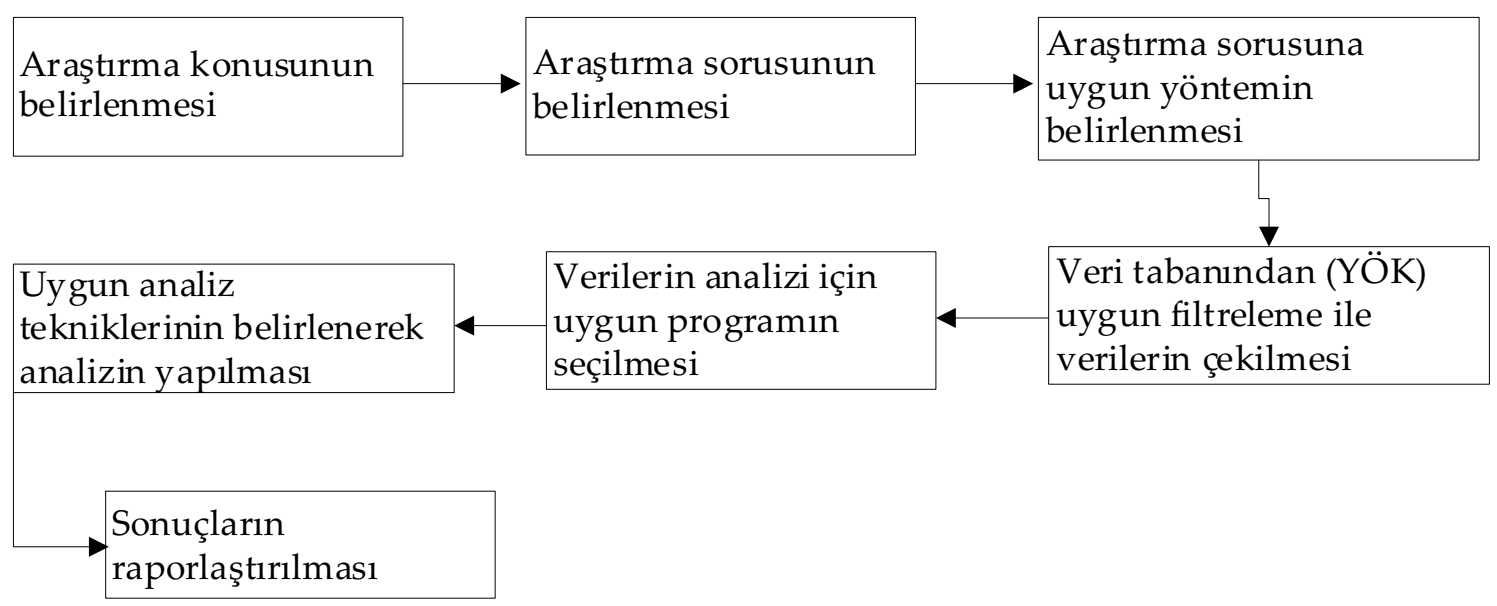

Şekil 1. Çalışma Akış Şeması

Araştırma kapsamında öncelikle Yükseköğretim Kurulu Tez Merkezi veri tabanında kayıtlı bulunan Rekreasyon Yönetimi Anabilim Dalında gerçekleştirilen lisansüstü tezlerin önceki kısımda açıklanan sorulara yanıt vermeye olanak sağlayacak parametreler ışığında değerlendirilebilmesi için YÖK'ün resmî internet sitesi üzerinden "Anabilim Dalı" sekmesi üzerinden "Rekreasyon Yönetimi"nin seçilmesiyle veri toplamaya başlanmıştır. Tarama sonucunda Rekreasyon Anabilim Dalı'nda yayımlanan 134 lisansüstü tez çalışması araştırmanın amacına uygun değişkenler -tezin alan, konu, yöntem, geçerlilik, güvenirlilik veya güvenduyulabilirlik ve normallik değerlemesi, kullanılan ölçme araçları, kullanılan istatistiksel teknikler- çerçevesinde, belirli bir sistematikle 01.07.2021-03.07.2021 tarihleri arasında Excel dosyasına alınmıştır. Toplanan veriler analize uygun hâle getirilerek Sosyal Bilimler İçin İstatistik Programı 25 (Statistical Package for the Social Sciences-SPSS) sürümüne aktarılmıştır. Verilerin analizinde temel betimsel istatistiksel tekniklerden yüzde, frekans dağılımları, grafikler ve basit karşılaştırmalar için çapraz tablo analiz testlerinden yararlanılmış; elde edilen bulgular takip eden kısımda raporlaştırılmıştır.

\section{BULGULAR}

Enstitülerin Rekreasyon Yönetimi Anabilim Dalı'nda yayımlanan lisansüstü tezlerin 2015 ile 2021 yılları arasında 12'si doktora, 122'sinin ise yüksek lisans olmak üzere toplamda 134 tezden oluştuğu belirlenmiştir. Yayımlanan tezlerin yıllık dağılımları değerlendirildiğinde 2015 yılından 2019 yılına kadar kayda değer bir yükselişin söz konusu olduğu görülmektedir. Buna göre doktora tezleri 2015 yılından 2018 yılına kadar birer artışla toplam 10 doktora tezi, 39 yüksek lisans tezi yayımlanmıştır. Yayımlanan yüksek lisans tezlerinde 2018 yılında bir sıçramanın 
olduğu görülmektedir. Diğer taraftan 2019 yılına gelindiğinde yayımlanan doktora tezi yalnızca bir (1) iken; yüksek lisans tezlerinde önceki yıla kıyasla iki katından fazla $(n=55)$ çalışmanın yayımlandığı belirlenmiştir. 2020 yılına gelindiğinde doktora tez sayısının yine yalnızca bir tane olduğu diğer yandan yüksek lisans tezlerinde de dikkat çekici bir azalışla yalnızca 19 çalışmanın yapıldığı saptanmıştır. Son olarak 2021 yılı Ağustos ayına gelindiğinde Yükseköğretim Kurulu Başkanlığı Tez Merkezine kayıtlı dokuz (9) yüksek lisans çalışmasının yer aldığı buna karşılık Rekreasyon Yönetimi Anabilim Dalı'nda hazırlanan bir doktora tezinin olmadığı saptanmıştır. Özellikle 2019 yılı sonrasındaki iki yılda meydana gelen bu dramatik düşüş, tüm dünyayı olduğu gibi ülkemiz eğitim öğretim hayatını da etkileyen, araştırmacıların saha çalışmalarını gerçekleştirmelerine engel olan küresel COVID-19 salgınıyla ilişkilendirilebilir (Şekil 2).

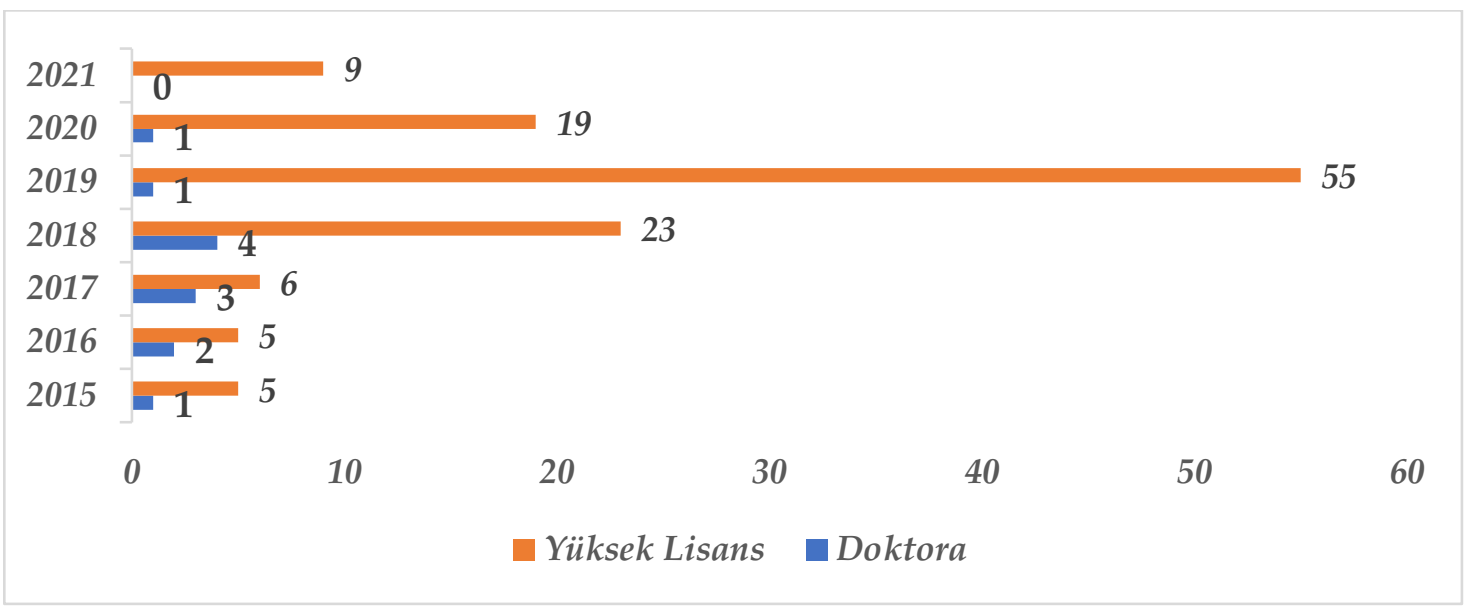

Şekil 2. Rekreasyon Yönetimi Anabilim Dalı'nda Yayımlanan Tez Türlerinin Yıllara Göre Dağılımı

Tablo 1. Rekreasyon Yönetimi Anabilim Dalı'nda Yayımlanan Tezlerin Alanlarına Göre Dağılımı

\begin{tabular}{lcc}
\hline \multirow{2}{*}{ Ilanlar* $^{*}$} & \multicolumn{2}{c}{ Yantlar } \\
\cline { 2 - 3 } & $\boldsymbol{N}$ & $\mathbf{\%}$ \\
\hline Spor & 79 & 38,9 \\
Turizm & 65 & 32,0 \\
İsletme & 21 & 10,3 \\
Eğitim Öğretim & 14 & 6,9 \\
Sosyoloji & 9 & 4,4 \\
Psikoloji & 5 & 2,5 \\
Kamu Yönetimi & 3 & 1,5 \\
Halk Sağlığı & 3 & 1,5 \\
Şehircilik ve Bölge Planlama & 1 & 0,5 \\
Ekonomi & 1 & 0,5 \\
İletişim bilimleri & 1 & 0,5 \\
Bilim ve Teknoloji & 1 & 0,5 \\
Toplam & $\mathbf{2 0 3}$ & $\mathbf{1 0 0 , 0}$ \\
\hline
\end{tabular}

*Alanlar incelenen tez sayısından fazladır 
Araştırma kapsamında Yükseköğretim Kurulu Başkanlığı Tez Merkezi sayfasında atanan sınıflandırmalar çerçevesinde Rekreasyon Yönetimi Anabilim Dalı'nda yayımlanan tezlere ilişkin araştırmaların yazarları tarafından seçilen konu dağılımları değerlendirilmiştir. Buna göre ilgili anabilim dalında yayımlanan tezler konu sınıflamaları bağlamında değerlendirildiğinde başta spor (\%38) ve turizm $(\% 32,8)$ olmak üzere; işletme (\%10,3), eğitim öğretim $(\% 6,9)$, sosyoloji $(\% 4,4)$, psikoloji $(\% 2,2)$, kamu yönetimi (\%1,5), halk sağllğı $(\% 1,5)$, şehir ve bölge planlama $(\% 0,5)$, ekonomi $(\% 0,5)$, iletişim bilimleri $(\% 0,5)$, bilim ve teknoloji $(\% 0,5)$ olmak üzere toplam 12 farklı çalışma alanında, çoğunluğu yüksek lisans olan çeşitli alanlarda çalışmaların gerçekleştirildiği belirlenmiştir (Tablo 1). Türkiye'de turizm ve spor alanındaki lisansüstü eğitimin "Rekreasyon Anabilim Dalı" ve "Rekreasyon Yönetimi Anabilim Dalı" ayrılmasına karşın hazırlanan tezlerin önemli bir kısmının spor alanında gerçekleşmesi hedeflenen uzmanlaşmanın henüz gerçekleşmediğini düşündürmüştür.

Rekreasyon Yönetimi Anabilim Dalı'nda yayımlanan 134 tezin her biri, araştırmacı tarafından tek tek incelenmiş ve yayımlanan tezler konu bağlamında ele alınmıştır. Aşağıda yer alan tabloda görüleceği üzere incelenen çalışmalarda ele alınan konu sayılarının birden fazla olması nedeniyle konu sayılarının incelenen tez sayısından fazla olduğu görülebilmektedir. Tablo incelendiğinde araştırmacıların en fazla ele aldığı rekreasyon konularının rekreatif aktiviteler (\%19,3) ve rekreasyon katılımı $(\% 16,4)$ olduğu; bu iki konuyu ise serbest zaman $(\% 7,2)$ ve yaşam $(\% 5,3)$ ile ilintili diğer konu başlıklarının takip ettiği; araştırmacıların serbest zaman ekseninde ele aldıkları unsurların ise algı, tatmin ve tutum olduğu görülmüştür. Tezler içerisinde yönetim alanında örgüt yapıları ilgili diğer konuların araştırmacıların en fazla ilgisini çeken diğer bir konu olduğu belirlenmiştir $(\% 3,4)$. Buna göre; tezlerde örgütsel bağlllık, örgütsel inovasyon, örgütsel nepotizm, örgütsel sinizm, örgütsel sessizlik ve örgütsel vatandaşlık konularının işlendiği görülmüştür. Hizmet kalitesi $(\% 2,9)$, destinasyon imajı ve markalaşması $(\% 2,4)$, pazarlama $(\% 2,4)$, açık alan rekreasyonu $(\% 2,4)$, motivasyon $(\% 2,4)$, benlik saygısı $(\% 1,9)$, zaman yönetimi becerisi ve tutumu $(\% 1,4)$ ve diğer $(\% 30,9)$ konu araştırmalarda ele alınan temel konular arasında yer almıştır. Burada dikkat çekilmesi gereken nokta diğer başlıkta ele alınan konular farklı ve çeşitlilik içermesi nedeniyle birleştirilmiştir. Tabloda Rekreasyon Yönetimi Anabilim Dalı'nda yayımlanan 22 farklı konu ele alınmış olmasına karşın tespit edilen yaklaşık 80 konu olmuş, kalan konuların ise "diğer" içerisinde verilmesi uygun görülmüştür (Tablo 2).

Rekreasyon Yönetimi Anabilim Dalı'nda yayımlanan lisansüstü tezlerin üniversitelere göre dağılımı aşağıdaki tabloda sunulmuştur (Tablo 3). Buna göre Gazi Üniversitesi Rekreasyon Yönetimi Anabilim Dalı'nda 38 tez yazılmıştır. Bu tezlerin bir kısmı (n=17) 2018 yılında üniversitenin adı Ankara Hacı Bayram Veli Üniversitesi olarak değişmeden önce yazılırken; kalan kısmı ise $(n=21)$ isim değişikliğinden sonra yazılmıştır. Ankara Hacı Bayram Veli Üniversitesi olarak ismi değiştikten sonra Rekreasyon Anabilim Dalı'nda ilk tez 2018 yılında ( $n=1)$ yazılmış; 2021 yılı Ağustos (5) ayı itibarıyla toplamda 15 lisansüstü tez yazılmıştır. Rekreasyon Anabilim Dalı'nda Türkiye' de en fazla lisansüstü tez yazılan diğer bir üniversite Batman Üniversitesi'dir. 2015 yılından 2021 yılına kadar 37 tez yazıldığı görülmektedir. Benzer oran ve sıklığa sahip olan Necmettin Erbakan ve Trakya Üniversitesi, her biri 19 lisansüstü tezle Rekreasyon Anabilim Dalı'nda tez hazırlanan üniversiteler arasında kayda değer ölçüde tez yazıldığı görülmüştür. Söz konusu anabilim dalında tez hazırlanan diğer üniversiteler arasında Karamanoğlu Mehmetbey Üniversitesi $(n=5)$ ile Manisa Celal Bayar Üniversitesi'nin $(n=1)$ yer aldığı belirlenmiştir. Türkiye'deki 78'i vakıf, 131'i ise devlet olmak üzere 209 üniversitede yalnızca altı farklı üniversitede bu alanda lisansüstü eğitimi veriliyor olması oldukça dikkat çekicidir. 
Tablo 2. Rekreasyon Yönetimi Anabilim Dalı'nda Yayımlanan Tezlerin Konularına Göre Dağglımı

\begin{tabular}{|c|c|c|c|}
\hline \multirow{2}{*}{ Konular* } & & \multicolumn{2}{|c|}{ Yanitlar } \\
\hline & & $\mathbf{N}$ & $\%$ \\
\hline Rekreatif aktiviteler & & 40 & 19,3 \\
\hline Rekreasyon Katılımı & & 34 & 16,4 \\
\hline \multirow{3}{*}{ Serbest Zaman } & Algisı & & \\
\hline & Tatmini & 15 & 7,2 \\
\hline & Tutumu & & \\
\hline \multirow{2}{*}{ Yaşam } & Kalitesi & & \\
\hline & Tatmini & 11 & b,3 \\
\hline \multirow{6}{*}{ Örgütsel } & Bağlılık & & \\
\hline & İnovasyon & & \\
\hline & Nepotizm & & \\
\hline & Sinizm & 7 & 3,4 \\
\hline & Sessizlik & & \\
\hline & Vatandaşlık & & \\
\hline \multirow{2}{*}{ Destinasyon } & İmajı & 5 & 24 \\
\hline & Markalaşması & 5 & 2,4 \\
\hline Pazarlama & & 5 & 2,4 \\
\hline \multirow{2}{*}{ Zaman Yönetimi Tutumu } & Becerisi & 3 & 1,4 \\
\hline & Tutumu & $J$ & \\
\hline Açık Alan Rekreasyonu & & 5 & 2,4 \\
\hline Motivasyon & & 8 & 3,9 \\
\hline Hizmet Kalitesi & & 6 & 2,9 \\
\hline Benlik Sayg1sı & & 4 & 1,9 \\
\hline Diğer & & 64 & 30,9 \\
\hline Toplam & & $207^{*}$ & 100,0 \\
\hline
\end{tabular}

${ }^{*}$ Konular incelenen tez sayısından fazladır.

Tablo 3. Rekreasyon Yönetimi Anabilim Dalı'nda Yayımlanan Tezlerin Üniversitelere Göre Dağılımı

\begin{tabular}{lll}
\hline Üniversite & Sikl $\boldsymbol{k} \boldsymbol{k}$ & Yüzde \\
\hline Ankara Hacı Bayram Veli Üniversitesi & 15 & 11,2 \\
Batman Üniversitesi & 37 & 27,6 \\
Gazi Üniversitesi & 38 & 28,4 \\
Karamanoğlu Mehmetbey Üniversitesi & 5 & 3,7 \\
Manisa Celal Bayar Üniversitesi & 1 &, 7 \\
Necmettin Erbakan Üniversitesi & 19 & 14,2 \\
Trakya Üniversitesi & 19 & 14,2 \\
Toplam & 134 & 100,0 \\
\hline
\end{tabular}

Araştırma kapsamında incelemeye alınan 134 lisansüstü tezin baskın çoğunluğunun nicel araştırma yaklaşımı $(\% 96,3)$; kalanlarının ise nitel araştırma (\%3,7) yaklaşımıyla gerçekleştirildiği belirlenmiştir. Nitel araştırma yöntemleri ile gerçekleştirilen tezlerin yüksek lisans tezi grubu 
içerisinde yer aldığı görülmüştür. Öte yandan terapötik rekreasyon gibi deneysel araştırma tasarımlarına olanak sağlayabilecek ve uygulamanın yanı sıra akademik alanyazına da dikkat çekici katkılar sunabilecek bir hizmet alanının bulunmasına karşın, Rekreasyon Yönetimi Anabilim Dalı araştırmacılarının bu araştırma tasarımına yeterince ilgi göstermediği, gerçekleştirilen araştırmaların büyük çoğunluğunun genel tarama, ilişkisel tarama ve betimsel araştırma tasarımı olmasından açık bir biçimde anlaşılabilmektedir.

Tablo 4. Rekreasyon Yönetimi Anabilim Dalı'nda Yayımlanan Tezlerde Başvurulan Yönteme Göre Dağılım

\begin{tabular}{lcc}
\hline Yöntem & Siklık & \% \\
\hline Nicel & 129 & 96,3 \\
\hline Nitel & 5 & 3,7 \\
\hline Toplam & 134 & 100,0 \\
\hline
\end{tabular}

Araştırma kapsamındaki tezlerden nicel araştırma yöntemlerinin kullanıldığı tezlerde en sık kullanılan veri toplama aracının ölçek olduğu saptanmıştır $(\% 74,7)$. Kullanılan ölçeklerin sosyal bilimlerde en çok kullanılan ölçme araçları içerisinden Likert tipi ölçek olduğu görülmüştür. Buna ek olarak tezlerde kullanılan veri toplama araçları oransal olarak büyükten küçüğe doğru sıralandığında; anketler $(\% 12)$, ilgi envanterleri $(\% 8,9)$, değerlendirme formu $(\% 1,3)$ ve son olarak belge/arşiv ve gözlem olmuştur. Veri toplama araçlarında ölçeğin kullanıldığı araştırmalar büyük ölçüde nedensel, ilişkisel ve hipotez içeren araştırma tasarımlarılyla gerçekleştirilirken anket, ilgi envanteri ve diğer ölçme araçlarının kullanıldığı araştırmalarda ise çoğunlukla tarama araştırmalarından yararlanıldığı belirlenmiştir.

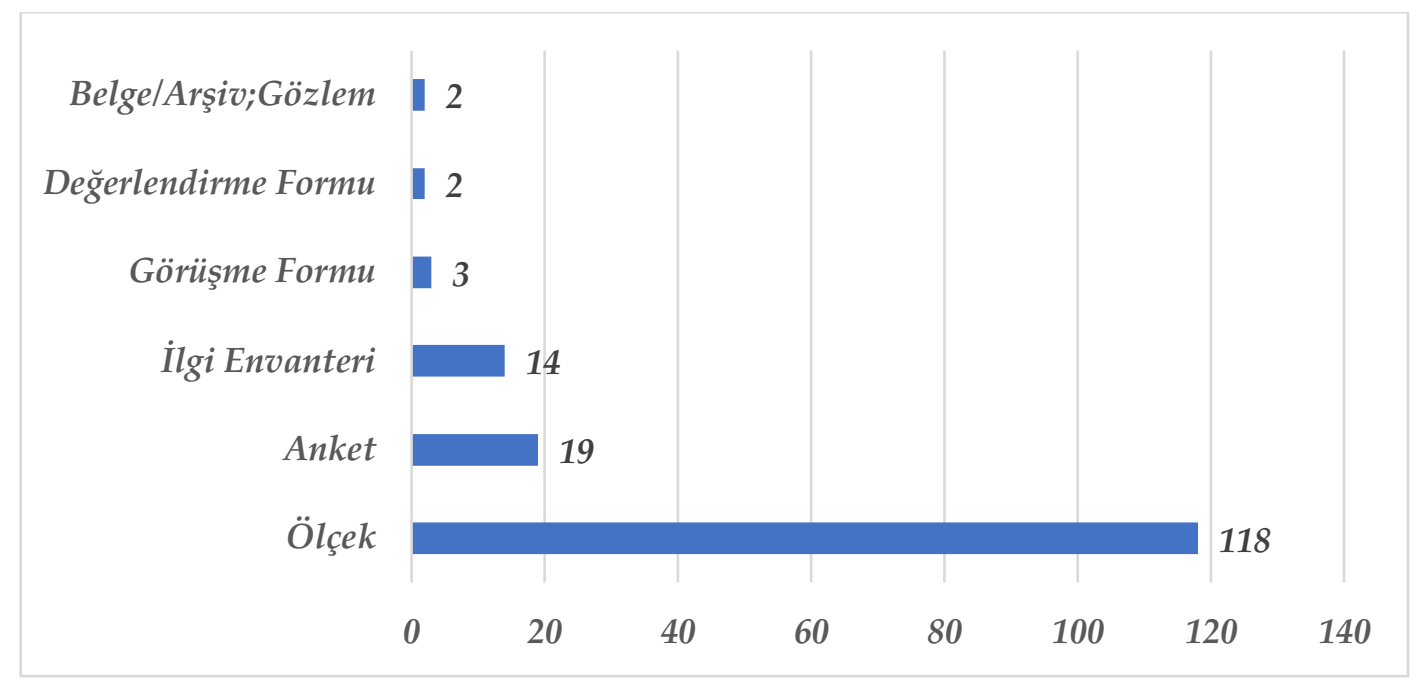

Şekil 3. Rekreasyon Yönetimi Anabilim Dalı'nda Yayımlanan Tezlerde Kullanılan Veri Toplama Araçlarına Göre Dağılım

*Araştırmalarda kullanılan ölçme aracı sayısı incelenen araştırma sayısını aşmaktadır.

Bilimsel araştırmalarda teorik olarak farklı durumları temsil eden geçerlilik ve güvenilirlik (Schmidt, Viswevaran ve Ones, 2000), elde edilecek bilimsel araştırma bulgu ve sonuçlarının daha sağlam bir zemine oturtulmasına önemli katkılar sunan, üzerinde titizlikle durulması gereken kavramlardır. Araştırmada kullanılan ölçme aracı ifadelerinin, araştırmaya katılan 
bireyler tarafından anlamlı ve mantıklı bulunmasıyla ilgili olan geçerlilik, en yalın ifadeyle bir ölçme aracında yer alan ifadelerin ve içeriğinin ölçeğin uygulandığı bağlamla ilgili olma derecesi olarak tanımlanabilir (Holden, 2010: 1; Connell vd., 2018: 1893). Geçerliliğin göreceli bir terim olduğunu öne süren Garret (1937: 354), belirli bir amaç veya durum için geçerli olan bir ölçme aracının genel olarak geçerli olamayabileceğini öne sürmektedir. Yaygın olarak; içerik, ölçüt, yapı ve yüzey olmak üzere dört farklı şekilde değerlendirilebilmektedir. Bilimsel araştırmalarda sunulması gereken ve çoğu kez göz ardı edilen bir diğer önemli konu, uygulama prosedürünün tekrar gerçekleştirilmesi durumunda ölçümün tutarlı olması anlamına gelen güvenilirliktir (Schmidt, Viswevaran ve Ones, 2000; Zhu, 2012: 62). İlgili literatürde başvurulan güvenilirlik teknikleri; iç tutarlılık, test-tekrar test, paralel formlar ve iki yarı veya yarıya bölme güvenilirlikleridir (MacPherson vd., 2014; Tulsky, 1990). Bunun yanı sıra yukarıda anlatılanlara benzer koşulların yerine getirilmesi konusu nitel araştırmalarda her iki kavrama karşılık gelen ve inandırıcllık, tutarlılık, doğrulanabilirlik ve aktarılabilirlik olmak üzere dört şekilde gerçekleştirilebilmenin mümkün olduğu güvenduyulabilirlik temel kavramı altında ele alınan (Guba, 1981) ölçütlerdir. Görüldügüü üzere nicel, nitel veya karma tüm araştırma yaklaşımları için uygulanabilecek -nicel araştırmalar için geçerlilik ve güvenilirlik ve nitel araştırmalar için güvenduyulabilirlik gibi- farklı tekniklerden bahsedebilmek mümkündür. Yukarıda açıklananlardan anlaşılacağı üzere farklı evren ve örneklemlerde gerçekleştirilen farklı araştırma tasarımlarında kullanılan benzer veya aynı ölçme araçlarının geçerlilik ve güvenirlilik test veya değerlendirmelerinin yapılması gerekmektedir. Buna rağmen Rekreasyon Anabilim Dalı'nda gerçekleştirilen yüksek lisans ve tezlerin baskın çoğunluğunun geçerlilik $(\% 82,1)$, yaklaşık yarısının ise güvenirlilik $(\% 43,3)$ test ve/veya değerlendirmelerinin yapılmadığı belirlenmiştir (Tablo 5). Bu bağlamda ilgili çalışmaların önemli bir kısmında elde edilen bulgu ve dolayısıyla raporlaştırılan sonuçların tartışmalı olduğunu öne sürmek mümkündür.

Tablo 5. Rekreasyon Yönetimi Anabilim Dalı'nda Yayımlanan Tezlerin Geçerlilik ve Güvenirlilik Değerlendirmelerine Göre Dağılımları

\begin{tabular}{lcccc}
\hline & \multicolumn{2}{c}{ Geçerlilik } & \multicolumn{2}{c}{ Güvenirlilik } \\
\cline { 2 - 5 } & Sıklık & $\%$ & Sıklık & $\%$ \\
\hline Evet & 24 & 17,9 & 76 & 56,7 \\
\hline Hayır & 110 & 82,1 & 58 & 43,3 \\
\hline Toplam & 134 & 100,0 & 134 & 100,0 \\
\hline
\end{tabular}

Nicel araştırma yaklaşımıyla gerçekleştirilen araştırmalarda, araştırmacıların hangi tür test tekniklerinden yararlanabileceklerini saptamak için toplanan verilerin normallik koşulunu sağlayıp sağlamadığını değerlendirmeleri gerekmektedir. Sosyal bilimlerde verilerin normallik ölçütlerini değerlendirmek üzere başvurulan temel yöntemler arasında merkezi eğilim ve yayılım ölçütleri, olasılık dağılımları, serpme diyagramları, Kolmogorov-Smirnov ve ShapiroWilk testleri (Field, 2009) gibi bir dizi çeşitli yöntem kullanılabilmektedir. Rekreasyon Yönetimi Anabilim Dalı'nda gerçekleştirilen 129 nicel yüksek lisans ve doktora tezinin yaklaşık üçte ikisinin veri analizlerine başlamadan önce normallik ölçütlerini sağlamaya yönelik test ve değerlendirmeler yaparken kalanların ise elde edilen verilerin normallik değerlendirmesi yapmadıkları veya tez metninde bunu raporlaştırmadıkları belirlenmiştir (Tablo 6). Normallik değerlemesi yapan araştırmacıların baskın çoğunluğunun çarpıklık, basıklık, aritmetik ortalama, mod, standart sapma gibi bazı merkezi eğilim ölçütlerinden yararlandıkları; az sayıda araştırmada ise Kolmogorov-Smirnov ve Shapiro-Wilk testlerinden yararlanıldığı belirlenmiştir. Tablo incelendiğinde normallik testi yapmayan araştırma sayılarının yüksek olması, incelenen 
tezlerin düzeyleri dikkate alındığında oldukça şaşırtıcıdır. Bunun temel nedeni yukarıda da ifade edildiği üzere sosyal bilimlerde nicel araştırma yaklaşımlarının tercih uygulandığı nedensel, ilişkisel ve hipotez içeren araştırma yaklaşımlarının tamamında parametrik veya non-parametrik testlerden en az birinin kullanılması gerekmektedir. Buna göre hangi grupta yer alan test türünün tercih edilmesi gerektiği sorunun yanitı ise ancak normallik değerlemesiyle mümkün olabilmektedir.

Tablo 6. Rekreasyon Yönetimi Anabilim Dalı'nda Yayımlanan Tezlerin Normallik Değerlemesine Göre Dağılımı

\begin{tabular}{ccc}
\hline Normallik & Siklık & $\boldsymbol{\%}$ \\
\hline Evet & 88 & 65,7 \\
\hline Hayır & 41 & 34,3 \\
\hline Toplam & 129 & 100,0 \\
\hline
\end{tabular}

Tablo 7. Rekreasyon Yönetimi Anabilim Dalı'nda Yayımlanan Tezlerde Kullanılan İstatistiksel Tekniklere Göre Dağılım

\begin{tabular}{lcc}
\hline \multirow{2}{*}{ Analiz Tekniği } & \multicolumn{2}{c}{ Yanıtlar } \\
\cline { 2 - 3 } & $\mathbf{N}$ & Yüzde \\
\hline Tek Yönlü Varyans Analizi & 73 & 21,9 \\
Bağımsız Örneklem T-testi & 68 & 20,4 \\
Korelasyon & 46 & 13,8 \\
Betimsel İstatistikler & 39 & 11,7 \\
Açımlayıcı Faktör Analizi & 12 & 3,6 \\
Regresyon & 26 & 7,8 \\
Mann-Whitney U Testi & 21 & 6,3 \\
Kruskal Wallis-H Testi & 18 & 5,4 \\
Ki-kare Testi & 12 & 3,6 \\
Bağımlı Örneklem T-testi & 5 & 1,5 \\
Wilcoxon İşaretli Sıralar Testi & 4 & 1,2 \\
Çok Değişkenli Varyans Analizi & 3 & 0,9 \\
Doğrulayıcı Faktör Analizi & 3 & 0,9 \\
Yol Analizi & 3 & 0,9 \\
Toplam & $333^{*}$ & 100,0 \\
\hline
\end{tabular}

*Analiz tekniği sayısı incelenen çalışma sayısını aşmaktadır.

İncelenen lisansüstü tezlerin normalliklerinin değerlendirilmesinden sonraki bu kısımda araştırmalarda uygulanması kararlaştırılan test teknikleri üzerinde durulmuştur. Yapılan araştırmalarda başvurulan analiz tekniklerine ilişkin bilgiler Tablo 7'de sunulmuştur. Buna göre beşi nitel, 129'u nicel olarak gerçekleştirilen çalışmada 14 farklı test türü olmak üzere toplamda 333 test tekniğinden yararlanılmıştır. Araştırmalarda tek yönlü varyans analizi (\%21), bağımsız örneklem t-testi (\%20,4), Pearson Korelasyon (\%12,1), Regresyon analizleri (\%7,8), çok değişkenli varyans analizi $(\% 0,9)$ olmak üzere parametrik testlerden yararlanıldığı belirlenmiştir. Diğer taraftan çalışmalarda kullanılan parametrik olmayan testler içerisinden en sık başvurulanların sırasıyla Mann-Whitney U Testi (\%6,3), Kruskal Wallis-H Testi $(\% 5,4)$, Ki-kare testi $(\% 3,6)$, Bağımlı Örneklem T-testi $(\% 1,5)$, Wilcoxon İşaretli Sıralar Testi $(\% 1,2)$ ve son olarak Sperman 
Korelasyon $(\% 1,7)$ testinden yararlandıkları belirlenmiştir. Araştırmalarda ayrıca ölçme araçlarına ilişkin yüzde ve frekans dağılımların verildiği betimsel istatistiklerin $(\% 11,7)$ yanı sıra açımlayıcı $(\% 3,6)$ ve doğrulayıcı $(\% 0,9)$ faktör analizleri ve yol analizlerinden $(\% 0,9)$ yararlanılmıştır. Analiz tekniğiyle ilgili not edilmesi gereken önemli bir konu normallik değerlemesi yapmayan araştırmacılardan bazılarının çalışmalarında doğrudan varyans analizi, bağımsız örneklem t-testi gibi parametrik testlere yöneldikleri görülmüsstür. Öte yandan incelenen araştırmalarda kullanılan analiz tekniklerinden varyans analizlerinin bir kısmında, Kruskal Wallis-H Testi analizlerinin ise tamamında, belirli koşulların oluşması sonucunda gerçekleştirilmesi gereken ileri düzey testlerin gerçekleştirilmediği dikkat çekmiştir. Varyans analizleri sonucu gerçekleştirilen ileri düzey testlerde araştırmacıların varyans eşitliği ölçütünün sağlandığ1 durumlarda Tukey $(n=35)$, Scheffe $(n=6)$, LSD $(n=6)$, Benferroni $(n=1)$; sağlanmadığında ise Tamhane's T2 $(n=6)$ ve Games-Howell $(n=1)$ post hoc çoklu karşılaştırmalarından yararlandıkları gözlenmiştir.

\section{SONUÇ ve ÖNERILER}

Bibliyometrik yöntemler, bilimsel çalışmalarla ilgili öznel yargılarla türetilen kategorilerin nicel doğrulamasını sunması, araştırılan konuyla ilgili alanların keşfedilmesi ve kategorilerin aydınlığa kavuşturulması için büyük bir potansiyel taşımaktadır (Zupic ve Čater, 2015:45). Bibliyometrik araştırmalar ayrıca gerçekleştirilen ölçümlerle mevcut literatürün bibliyografik kontrolünü sağlayarak, yayımlanmış çalışmalarla büyüyen araştırma alanının güçlü ve zayıf yönlerine dikkat çeker (Baladi vd., 2018). Bu düşüncelerden hareketle yürütülen bu araştırma sonuçları, Rekreasyon Yönetimi Anabilim Dalı'ndaki lisansüstü tezlerin (n=134) ilk kez 2015 yılında yayımlandığını göstermiştir. Rekreasyon Yönetimi Anabilim Dalı'nda yayımlanan tezlerin ağırlıklı olarak yüksek lisans olduğu $(n=122)$ görülmüş, sayıca az olsa $(n=12)$ da doktora tez çalışmalarının yapıldığı da belirlenmiştir. Doktora çalışmalarının sayısındaki azlığın nedenlerinden birinin alanın oldukça yeni olması gösterilebilir. Alanda yazılan tezlerin ilk dört yılında hem yüksek lisans hem de doktora tezleri bağlamında artış gösterdiği belirlenmişse de son iki yıl içerisinde (2020-2021) bu sayıda görece bir azalışın olduğu belirlenmiştir. Meydana gelen azalışı, dünyayı etkisi altına alan ve eğitim-öğretim hizmetlerinde dünyada olduğu gibi ülkemizde de önemli olumsuz etkileri bulunan COVID-19 salgınıyla ilişkilendirmek olanaklıdır. Nitekim bu tarihlerin önemli bir kısmında yüz yüze eğitimler yapılamamış, araştırmacıların saha araştırması yapması kısıtlamalar nedeniyle neredeyse imkânsız hâle gelmiştir.

Rekreasyon Yönetimi Anabilim Dalı'nda yayımlanan tezler, alan özelinde değerlendirildiğinde spor, turizm, işletme ve eğitim öğretimin ağırlıkta olduğu belirlenmiştir. Turizm ve spor alanındaki lisansüstü eğitimin anabilim dallarınca ayrılmasına karşın hazırlanan tezlerinin önemli bir kısmının spor alanında gerçekleşmesi hedeflenen uzmanlaşmanın henüz gerçekleşmediğini düşündürmüş̧ür. Ancak bu noktada not edilmesi gereken konu sosyoloji ve halk/toplum sağlığı gibi kamuyu ilgilendiren yönü fazla olan, dahası psikolojik düzlemde birey ve gruplara katkısı bilinen alanda bu yöndeki çalışmalara yeterince yer verilmemesi dikkat çekicidir. Öte yandan terapötik rekreasyon gibi deneysel araştırmalara elverişli bir çalışma alanına sahip olan Rekreasyon Yönetimi Anabilim Dalı'nda bu bağlamda gerçekleştirilecek araştırmaların, teorinin yanı sıra uygulamaya da önemli katkılar sağlayacağı öne sürülebilir.

Yayımlanan çalışmalar daha spesifik bir şekilde ele alınmış, her bir çalışma konu özelinde değerlendirilmiştir. Buna göre araştırmacılar çalışmalarını önemli bir oranda rekreatif aktiviteler ve rekreasyon katılımı bağlamındaki konular ekseninde gerçekleştirdikleri, bu konuyu ise serbest zamanla ilgili konular -alg1, tatmin, tutum- sonrasında ise yaşam tatmini ve yaşam kalitesi konularının takip ettiği belirlenmiştir. Araştırmacıların ayrıca örgütsel konulara ilgi duydukları 
saptanmış bununla ilgili en fazla bağlılık, inovasyon, nepotizm, sinizm, sessizlik ve vatandaşlığın ele alındığı görülmüştür. İlgi duyulan konular bir bütün olarak değerlendirildiğinde konuların büyük oranda pazarlama ve yönetim araştırmalarının kapsamına girdiği görülmüştür.

Yayımlanan tezler kurumlara göre değerlendirildiğinde Rekreasyon Yönetimi Anabilim Dalı'nda yayımlanan tezlerin üçte birden fazlasının Türkiye'nin bu alanda en köklü üniversitelerinden olan eski adıyla Gazi Üniversitesi yeni adıyla Ankara Hacı Bayram Veli Üniversitesi'nde yayımlandığı tespit edilmiştir. Bu anabilim dalında en fazla mezun veren diğer üniversiteler ise Batman üniversitesi, Necmettin Erbakan Üniversitesi ve Trakya Üniversitesi'dir. Toplam altı farklı üniversitenin rekreasyon yönetimi anabilim dalında lisansüstü verdiği belirlenmiştir. En az tezin yayımlandığı Manisa Celal Bayar Üniversitesi'nde 2018 yılından bu yana yalnızca bir yüksek lisans çalışmasının yapıldığı saptanmıştır.

İncelenen 134 lisansüstü tez çalışmasında başvurulan araştırma yöntemleri incelenmiş; buna göre araştırmaların büyük çoğunluğunda nicel, az bir kısmında ise nitel yaklaşımlardan yararlanıldığ1 belirlenmiştir. Araştırmaların hiçbirinde son yıllarda sosyal bilimler alanında rağbet gören karma araştırma yöntemlerinden yararlanılmadığ 1 görülmüştür. İncelenen tezler içerisinde doktora tezlerinin tamamında nicel araştırma yöntemlerinin benimsendiği görülürken, nitel araştırma yöntemlerinin yüksek lisans tez türünde tercih edildiği saptanmıştır. Nitel ve nicel araştırma yaklaşımıyla gerçekleştirilen araştırmaların genel tarama, ilişkisel tarama ve betimsel araştırma tasarımlarıyla gerçekleştirildiği ortaya koyulmuştur. Bu sonuçlardan hareketle alanda gelecekte araştırma yapacak araştırmacılar için deneysel ve keşifsel araştırma tasarımlarına ilgi göstermeleri önerilebilir.

Nicel araştırmaların çoğunlukta olduğu lisansüstü tez çalışmalarında veri toplama aracı olarak sosyal bilim araştırmalarında yaygın bir şekilde kullanılan Likert tipi ölçek olduğu, bunu bir derecelendirmenin bulunmadığı anket formlarının izlediği belirlenmiştir. Ölçme araçlarının geçerlilik ve güvenirlilik ölçütlerine ilişkin değerlemenin yapılıp yapılmadığının incelendiği araştırmaların dörtte üçten fazlasının geçerlilik; yaklaşık olarak yarısının ise güvenirlilik ölçütlerini sağlamaya yönelik test veya değerlemeleri yapmadıkları belirlenmiştir. Buna ek olarak araştırmalarda analizler öncesinde elde edilen verilerin normallik koşulunu sağlayıp sağlamadığına ilişkin yapılan incelemeler sonucunda tezlerin üçte birden fazlasının verilerin normallik koşulunu değerlendirmedikleri tespit edilmiştir. Son olarak incelenen 134 lisansüstü tezin önemli bir kısmında parametrik testlerden tek yönlü varyans analizi, bağımsız örneklem ttesti, Pearson Korelasyon ve regresyon analizlerinden diğer taraftan araştırmaların bir kısmında ise bu testlerin parametrik olmayan karşılıkları olan Mann Whitney-U, Kruskal Wallis $\mathrm{H}$, Sperman Korelasyon ve Wilcoxon işaretli sıralar testi kullanıldığı belirlenmiştir. İncelenen tezlerde üst düzey analiz tekniklerine hakimiyet gerektiren testlerden oldukça sinırlı sayıda yararlanılmış olması dikkat çekicidir. Diğer taraftan çok sayıda araştırmada normallik değerlemesi yapılmadan parametrik testlerden yararlanılması önemli bir sorun olarak değerlendirilebilir. Nitekim bu durum elde edilen sonuçları doğruluğuna, geçerli ve güvenilir olma durumlarına ilişkin önemli soruları beraberinde getirmektedir ki geçerlilik ve güvenilirlik ölçütlerinin sağlanması bağlamında da araştırmalarda önemli eksiklikler saptanmıştır. Gelecek araştırmalarda araştırmacıların araştırma tasarımı noktasında daha özenli ve dikkatli olmalarının ve tercih ettikleri ölçme araçlarını pilot bir araştırmayla test etmelerinin, rekreasyon yönetimi araştırmalarının daha sağlam temeller üzerine inşa edilmesine katkı sağlayacağı söylenebilir. Yapılan incelemelerde rekreasyon yönetimi anabilim dalı araştırmacılarının çalışma alanı olarak terapötik rekreasyonu, araştırma yaklaşımı olarak nitel araştırmaları ve uygulamalı -nedensel ve hipotez içeren- araştırmalar olarak deneysel araştırmaları ihmal ettikleri anlaşılmıştır. Gelecek araştırmacıların bu konulara eğilmeleri, teori ve uygulamaya önemli katkılar sağlayacaktır. Rekreasyon Yönetimi Anabilim Dalı'nın ülkemizde lisansüstü geçmişi göz önünde 
bulundurulduğunda henüz yolun çok başında olduğumuzu ve alınacak önemli mesafelerin olduğunu ifade etmek mümkündür.

Üniversitelerin Rekreasyon Yönetimi Anabilim dallarında yayımlanan ve Yükseköğretim Kurulu Başkanlığı Tez Merkezi'nde kayıtlı bulunan lisansüstü tezlerin yayımlandığı üniversite, alan, konu, tür, yöntem, veri toplama araçları, geçerlilik, güvenirlilik ve normallik değerlemesi ve analiz tekniği parametreleri temel alınarak değerlendirilen bu çalışma, son yıllarda alanda gerçekleştirilen çalışmaların bir bütün olarak değerlendirilebilmesine katkı sağlayacağı gibi, gelecek araştırmacılar için yayımlanan çalışmalarla ilgili temel bazı bilgilerin sunulduğu bir kılavuz niteliği taşımaktadır. Araştırma kapsamında ortaya konulan sonuçlar, Rekreasyon Yönetimi Anabilim Dalı'nda eğitim-öğretim hayatını sürdüren araştırmacılara, mevcut eğilimlere, alanla ilgili var olan boşlukları ön görebilmeye ve teknik bazı konularda dikkat edilmesi gereken durumlara ilişkin kayda değer ipuçları vermesi bakımından önem taşımaktadır. Buna göre bu çalışma, gelecekte hazırlanacak lisansüstü çalışmaların daha nitelikli yürütülmesine katkı sağlayacaktır.

\section{KAYNAKÇA}

Aksöz, E. O. ve Yücel, E. (2020). Engelli Turizmi Alanındaki Lisansüstü Tezlerin Bibliyometrik Analizi, Türk Turizm Araştırmaları Dergisi, 4(1): 388-404.

Alimanoğlu, Ç. ve Arıkan Saltık, I. (2020). Turizmde Örgütsel Davranış Çalışmaları: Adım Üniversiteleri'nde Tamamlanan Lisansüstü Tezler Üzerine Bibliyometrik Bir Araştırma (19952018), Journal of Travel and Tourism Research, 17(Autumn): 27-51.

Alimanoğlu, Ç. ve Çolakoğlu, Ü. (2021). Türkiye'deki Turizm Rehberliği Konulu Lisansüstü Tez Çalışmalarının Bibliyometrik Profili (1998-2018), Journal of Travel and Tourism Research, 18(Autumn): 51-67.

Alimanoğlu, Ç. ve Ayazlar, G. (2017). Türkiye'de Kırsal Turizm Konulu Lisansüstü Tez Çalışmaları Üzerine Bibliyometrik Bir İnceleme (2003-2016), Uluslararası Kırsal Turizm ve Kalkınma Dergisi (IRTAD) E-ISSN: 2602-4462, 1(1): 6-12.

Altaş, A. ve Acar, Y. (2018). Bibliometric Profile of the Postgraduate Dissertations Written in the Field of Gastronomy, Aksaray Üniversitesi İktisadi ve İdari Bilimler Fakültesi Dergisi, 10(3): 1-10.

Arıkan Saltık, I. (2020). Turist Rehberliği Konulu Ulusal Lisansüstü Tezlerin Bibliyometrik Profili (1989-2018), ÇAKÜ Sosyal Bilimler Enstitüsü Dergisi, 11(1): 45-69.

Arslan, E. ve Emeksiz, M. (2016). Konaklama İşletmelerinde Çevre Yönetimi Konusunun Bibliyometrik Profili ve Gelecek Çalışmalar İçin Öneriler, Disiplinlerarası Akademik Turizm Dergisi, 1(1): 1-12.

Arslan, E, Aydın Arslan, S. ve Coşkun, İ. O. (2017). Science Direct Veri Tabanında Taranan Dergilerin Bibliyometrik Analizi: Turizm Talebi Üzerine Yapılan Çalışmaların İncelenmesi, 17. Ulusal Turizm Kongresi, 20-23 Ekim 2016, Bodrum, Muğla, ss: 1446-1459.

Aydın, B. ve Aksöz, O. E. (2019). Destinasyon Alanında Yayınlanmış Lisansüstü Tezlerin Bibliyometrik Profili, Journal of Tourism and Gastronomy Studies, 7(1): 615-636.

Aydın, B. ve Arslan, E. (2016). The Role of Social Media on Leisure Preferences: A Research on the Participants of Outdoor Recreation Activities, Turizm Akademik Dergisi, 3(1): 1-10.

Baladi, Z. H., Haq, I. U., Hussain, M., and Elahi, G. (2018). Pakistan Journal of Pharmaceutical Sciences: A Bibliometric Assessment from 1998-2012, Library Philosophy and Practice, 1743: 1-16. 
Baştuğ, G., Zorba, E., Duyan, M. ve Çakır, Ö. (2017). Farklı Kültürlerde Rekreasyon: Serbest Zaman Aktivitelerinin İncelenmesi, Journal of Human Sciences, 14(4): 3895-3904.

Boyraz, M., Kabakulak, A., ve Mutlu, A. S. (2021). Hazırlanmakta Olan Turizm Konulu Lisansüstü Tezlerin Veri Görselleştirme Tekniği ile Bibliyometrik Analizi: 2006-2020 Y1lları Örneği, Türk Turizm Araştırmaları Dergisi, 4(2), 1434-1453.

Broadus, R. N. (1987). Toward a Definition of “Bibliometrics", Scientometrics, 12(5-6): 373-379.

Büyükşalvarcı, A. ve Keleş, H. (2019). Turizm Alanında Yazılan Lisansüstü Tezlerin Bibliyometrik Açıdan İncelenmesi, Journal of Tourism and Gastronomy Studies, 7(4): 2758-2773.

Cobo, M. J., López-Herrera, A. G., Herrera-Viedma, E., and Herrera, F. (2011). Science Mapping Software Tools: Review, Analysis, and Cooperative Study among Tools, Journal of the American Society for information Science and Technology, 62(7): 1382-1402.

Connell, J., Carlton, J., Grundy, A., Buck, E. T., Keetharuth, A. D., Ricketts, T., and Brazier, J. (2018). The Importance of Content and Face Validity in Instrument Development: Lessons Learnt from Service Users When Developing the Recovering Quality of Life Measure (ReQoL). Quality of Life Research, 27(7): 1893-1902.

Çapar, G., Toksöz, D. ve Dönmez, B. (2018). Turizm Rehberliği Alanında Yapılan Akademik Çalışmaların İncelenmesi, Turist Rehberliği Dergisi (TURED), 1(2): 57-73.

Çıkrık, R, Yılmaz, İ. ve Toprak, L. (2019). Turizmin Etkileri Konusunda Yerel Halkın Bakış Açısını Konu Alan Lisansüstü Tezlerin Bibliyometrik Profili, Journal of Hospitality and Tourism, 1(1): 1729.

Çuhadar, M. ve Morçin, İ. (2020). Türkiye'de Gastronomi Turizmi ile İlgili Çalışmaların Bibliyometrik Analizi, Journal of Recreation and Tourism Research, 7(1), 92-106.

Demirbulat, Ö. G. ve Dinç, N. T. (2017). Sürdürülebilir Turizm Konulu Lisansüstü Tezlerin Bibliyometrik Profili, Seyahat ve Otel İşletmeciliği Dergisi, 14(2): 20-30.

Field, A. (2009). Discovering Statistics Using SPSS: Introducing Statistical Method (3rd ed.). Thousand Oaks, CA: Sage.

Galton, F. (1874). English Men of Science: Their Nature and Nurture. London: Macmillan.

Garret, Henry E. (1937). Statistics in Psychology and Education. New York: Longmans, Green and Co.

Guba, E. G. (1981). Criteria for Assessing the Trustworthiness of Naturalistic Inquiries, Educational Communication and Technology: A Journal of Theory, Research and Development, 29(2): 75- 91.

Güçlü Nergiz, H. (2014). Türkiye'de Lisansüstü Turizm Tezlerinin Bibliyometrik Profili (19902013), VII. Lisansüstü Turizm Öğrencileri Araştırma Kongresi, 04-05 Nisan 2014, Kuşadası, Aydın, ss. 212-221.

Gül, M. and Gül, K. (2018). Bibliometric Profile of Graduateand Post-Graduate Theses on Rural Development and Rural Tourism, International Journal of Social and Economic Sciences, 8(2): 56-62.

Holden, R. B. (2010). Face Validity. (Editors) Weiner, I. B. and Craighead, The Corsini Encylopedia of Psychology in (pp. 637-638): Hoboken, NJ: Wiley.

IBM Corp. Released (2017). IBM SPSS Statistics for Windows, Version 25.0. Armonk, NY: IBM Corp. 
İçöz, O. ve Kozak, N. (1999). Turizm İşletmeciliği Dergisi'nin Turizm Literatürüne Katkısı Hakkında Bir İnceleme, Anatolia: Turizm Araştırmaları Dergisi, 10(2): 9-17.

Kervankıran, İ., Eteman, F. S. ve Şardağ, A. (2019). Türkiye'de Turizm Coğrafyası Araştırmalarında Disipliner İlişkinin Sosyal A $\breve{g}$ Analizi ile İncelenmesi, Gaziantep University Journal of Social Sciences, 18(3): 938-965.

Köşker, H. (2020). Coğrafi İşaret Konusunda Yazılmış Lisansüstü Tezlerin Bibliyometrik Analizi, Journal of Humanities and Tourism Research, 10(4): 775-787.

López-Bonilla, J. M., and López-Bonilla, L. M. (2021). Leading Disciplines in Tourism and Hospitality Research: A bibliometric Analysis in Spain, Current Issues in Tourism, 24(13): 18801896.

Lian, T., Yu, C., Wang, W., Yuan, Q., and Hou, Z. (2016). Doctoral Dissertations on Tourism in China: A Co-Word Analysis, Ko-Knowledge Organization, 43(6): 440-461.

MacPherson, S. E., Wagner, G. P., Murphy, P., Bozzali, M., Cipolotti, L., and Shallice, T. (2014). Bringing the Cognitive Estimation Task into the 21st Century: Normative Data on Two New Parallel Forms, PloS one, 9(3): e92554.

Nusair, K., Butt, I., and Nikhashemi, S. R. (2019). A Bibliometric Analysis of Social Media in Hospitality and Tourism Research, International Journal of Contemporary Hospitality Management, 31(7): 2691-2719.

Örnek, N. ve Karamustafa, K. (2020). Turist Rehberliği Alanındaki Lisansüstü Tezlerin Bibliyometrik Analiz ile Değerlendirilmesi (1989-2019), Turist Rehberliği Dergisi, 3(2): 115-138.

Özsoy, A. ve Çokal, Z. (2018). Türkiye'de Turist Rehberliği Alanında Yayımlanmış Lisansüstü Tezlerin Bibliyometrik Analizi (1989-2018), 2. International EMI Entrepreneurship and Social Sciences Congress, Nevşehir, Türkiye.

Palmer, A. L., Sesé, A., and Montaño, J. J. (2005). Tourism and Statistics: Bibliometric Study 19982002, Annals of Tourism Research, 32(1): 167-178.

Polat, E., Düzgün, E. ve Yeşiltaş, M. (2019). İklim Değişikliğinin Turizme Etkisini Belirlemeye Yönelik Hazırlanan Lisansüstü Tezlerin Bibliyometrik Profili, Gümüşhane Üniversitesi Sosyal Bilimler Enstitüsü Elektronik Dergisi, 10: 240-249.

Pritchard, A. (1969). Statistical Bibliography or Bibliometrics?, Journal of Documentation, 25: 348349

Reitz, J. M. (2005). ODLIS- Online dictionary for library and information science. Erişim adresi: https://products.abc-clio.com/ODLIS/odlis_b [Erişim Tarihi: 08.08.2021].

Resmî Gazete (2009). 13 Kasım 2009 Tarihli ve 27405 Sayılı Resmî Gazete, https://www.resmigazete.gov.tr/eskiler/2009/11/20091113.htm, [Erişim Tarihi: 02.08.2021).

Ruhanen, L., Weiler, B., Moyle, B. D., and McLennan, C. L. J. (2015). Trends and Patterns in Sustainable Tourism Research: A 25-year Bibliometric Analysis, Journal of Sustainable Tourism, 23(4): 517-535.

Schmidt, F. L., Viswesvaran, C., and Ones, D. S. (2000). Reliability is not Validity and Validity is not Reliability, Personnel Psychology, 53(4): 901-912.

Singh, K. P., Chander, H., and Sharma, R. (2020). Bibliometric Study of Publications in Conference Proceedings of SRFLIS Summit during 2014-2019, International Journal of Digital Content Management, 1(1): 9-26. 
Sünnetçioğlu, A., Yalçınkaya, P., Olcay, M. ve Okan, Ş. (2017). Turizm Alanında Yazılmış Olan Gastronomiye İlişkin Tezlerin Bibliyometrik Profili, Journal of Tourism and Gastronomy Studies, 5(2): 345-354.

Şahin, E., Akdağ, G., Çakıcı, C. ve Onur, N. (2018). Gastronomi ve Mutfak Sanatları Anabilim Dallarında Yayınlanan Tezlerin Bibliyometrik Analizi, Güncel Turizm Araştırmaları Dergisi, 2(Ek1): 30-41.

Tayfun, A., Ülker, M., Gökçe, Y., Tengilimoğlu, E., Sürücü, Ç. ve Durmaz, M. (2018). Turizm Alanında Yiyecek ve İçecek ile İlgili Lisansüstü Tezlerin Bibliyometrik Analizi, Journal of Tourism and Gastronomy Studies, 6(2): 523-547.

Tulsky, D. S. (1990). An Introduction to Test Theory, Oncology Williston Park, New York, 4(5): 4348.

Turan, A. (2014). Turizm Konulu Yüksek Lisans Tezlerinin Bibliyometrik Özellikleri (1984-2013), VII. Lisansüstü Turizm Öğrencileri Araştırma Kongresi, 04-05 Nisan 2014, Kuşadası, Aydın, ss. 3-15.

Ünal, A. ve Bayar, S. B. (2020). Türkiye'de Destinasyon Konusunda Yayınlanmış Lisansüstü Tezlerin Bibliyometrik İncelenmesine Yönelik Bir Araştırma, Karadeniz Sosyal Bilimler Dergisi, 12(22): 237-250.

Vishwakarma, P., and Mukherjee, S. (2019). Forty-Three Years Journey of Tourism Recreation Research: A Bibliometric Analysis, Tourism Recreation Research, 44(4): 403-418.

Weiler, B., Moyle, B., and McLennan, C. L. (2012). Disciplines that Influence Tourism Doctoral Research: The United States, Canada, Australia and New Zealand, Annals of Tourism Research, 39(3): 1425-1445.

Yedinci Beş Yıllık Kalkınma Planı (2021). https://www.sbb.gov.tr/wpcontent/uploads/2018/11/Yedinci-Be\%C5\%9F-Y\%C4\%B111\%C4\%B1k-Kalk\%C4\%B1nma-

Plan\%C4\%B1-1996-2000\%E2\%80\%8B.pdf, [Erişim Tarihi: 01.08.2021].

Yersüren, S. ve Özel, Ç. H. (2020). Boş Zaman ve Rekreasyon Konulu Tezler Üzerine Bibliyometrik Bir Çalışma. Türk Turizm Araştırmaları Dergisi, 4(2): 1139-1159.

Yıldırım, O. (2021). Ulusal Alan Yazında Spor Turizminin Gelişimi: Lisansüstü Tezler Üzerine Bibliyometrik Bir Analiz, Pamukkale Üniversitesi Sosyal Bilimler Enstitüsü Dergisi, 43: 319-331.

Yüksek Öğretim Bilgi Yönetim Sistemi (2021). https://istatistik.yok.gov.tr/, [Erişim tarihi: 01.08.2021].

Yüksek Öğretim Kurulu Başkanlığı Tez $\quad$ Merkezi https://tez.yok.gov.tr/UlusalTezMerkezi/, [Erişim tarihi: 01.07.2021].

Zengin, B. ve Atasoy, B. (2020). Turizm Rehberliği Alanındaki Lisansüstü Tezlerin Bibliyometrik Çerçevesi, Alanya Akademik Bakış, 5(1): 143-160.

Zhu, W. (2013). Reliability: What type, please!, Journal of Sport and Health Science, 2(1): 62-64.

Zorba, E. (2007). Türkiye'de Rekreasyona Bakış Açısı ve Gelişimi, Gazi Haber Dergisi, 52-55.

Zupic, I., and Čater, T. (2015). Bibliometric Methods in Management and Organization, Organizational Research Methods, 18(3): 429-472. 